\title{
Dentists' knowledge regarding signs and symptoms of the systemic toxicity of local anesthetic solutions
}

\author{
Conhecimento de cirurgiões-dentistas sobre sinais e sintomas de toxicidade sistêmica associados ao uso \\ de soluções anestésicas locais
}

Ana Carolina PINHEIRO'

Jayne França MARQUES²

Mayana Soares VIEIRA ${ }^{3}$

Luciana Salles BRANCO-DE-ALMEIDA ${ }^{4}$

\section{ABSTRACT}

\section{Objective}

To evaluate the knowledge of dentists about signs and symptoms that may be indicative of systemic toxicity associated with the use of local anesthetic solutions.

\section{Methods}

One hundred and twenty-four (124) dentists from private clinics in São Luís (Maranhão, Brazil) answered a questionnaire regarding the choice of solutions, selection criteria for local anesthetics and vasoconstrictors, and side effects associated with these substances. Results were analyzed by using descriptive statistics.

\section{Results}

Although most respondents reported being likely to choose local anesthetics at less toxic concentrations (including $2 \%$ mepivacaine or lidocaine), they were also likely to have similar vasoconstrictor solutions (epinephrine) as the second choice. The main selection criteria of anesthetic solutions reported were the duration of procedures and patients' individual characteristics. In general, dentists demonstrated being aware of some side effects associated with vasoconstrictors; however, they showed a lack of knowledge regarding signs and symptoms related to an overdose of local anesthetics.

\section{Conclusion}

The group of dentists involved in this study showed limited knowledge about the toxicity of local anesthetics, as well as some inconsistent background over the choice of vasoconstrictors. Thus, strategies are required towards improving the knowledge of professionals from private dental clinics regarding local anesthetics and/or vasoconstrictors.

Indexing terms: Local anesthetics. Vasoconstrictor agents. Toxicity.

\section{RESUMO}

\section{Objetivo}

Avaliar as soluções anestésicas utilizadas por um grupo de cirurgiões-dentistas e o nível de conhecimento desses profissionais sobre riscos associados a essas substâncias.

\section{Métodos}

Cento e vinte e quatro (124) cirurgiões-dentistas da rede privada do município de São Luís (Maranhão, Brasil) responderam um questionário contendo perguntas relativas às soluções de escolha, aos critérios de escolha de anestésicos locais e vasoconstritores e à avaliação do conhecimento sobre os efeitos colaterais associados às substâncias.

\section{Resultados}

Os resultados obtidos foram analisados utilizando-se estatística descritiva. Observou-se que a maior parte dos cirurgiões-dentistas optaram por anestésicos locais em concentrações menos tóxicas, como a mepivacaína $2 \%$ e a lidocaína $2 \%$, porém se verificou que a maioria dos profissionais optaram pelo mesmo vasoconstritor (epinefrina) em soluções de segunda escolha. Os principais critérios de escolha das soluções anestésicas foram a duração do procedimento e as características do paciente. Analisando os dados em conjunto, os cirurgiões-dentistas pareceram conhecer alguns efeitos colaterais associados a vasoconstritores, porém demonstraram uma deficiência no conhecimento de sinais e sintomas relacionados à sobredosagem de anestésicos locais.

\section{Conclusão}

Concluiu-se que o grupo de cirurgiões-dentistas envolvido no presente estudo apresentou conhecimento limitado em relação à toxicidade de anestésicos locais, bem como contradição em relação à escolha de vasoconstritores. Estratégias para aprofundar o conhecimento sobre anestésicos locais e/ou vasoconstritores de profissionais da rede privada são necessárias.

Indexing terms: Termos de indexação: Anestésicos locais. Toxicidade. Vasocontritores.

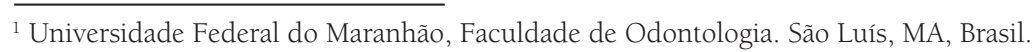

${ }^{2}$ Universidade Ceuma, Faculdade de Odontologia. São Luís, Maranhão, Brasil.

${ }^{3}$ Universidade Ceuma, Departamento de Pós-Graduação em Odontologia. São Luís, Maranhão, Brasil.

${ }^{4}$ Universidade Federal do Maranhão, Departamento de Odontologia II. Av. dos Portugueses, 1.966, Bacanga, 65085-580, São Luís, MA, Brasil. Correspondência para / Correspondence to: LS BRANCO-DE-ALMEIDA. E-mail: <luciana.salles@ufma.br>.
} 


\section{INTRODUCTION}

A safe and effective local anesthesia, which is one of the most frequent and important approaches for controlling the pain in Dentistry, is essential towards achieving the patient care. Hence, among other factors, it is important for local anesthetics to show rapid onset of action, provide adequate duration of anesthesia, and be composed by substances (i.e. local anesthetics, vasoconstrictors) with minimal or no systemic toxicity ${ }^{1-2}$.

The main mechanism of action proposed for local anesthetics (LAs) is related to the binding of these substances to sodium channels receptors $\left(\mathrm{Na}^{+}\right)$, leading to the reduction or elimination of the permeability of these ions and interruption of the nervous conduction ${ }^{3-4}$. The most widely used LAs in dentistry are those containing an amide bond, of which 2-3\% lidocaine or mepivacaine, $3 \%$ prilocaine, $0.5 \%$ bupivacaine, and $4 \%$ articaine (injectable form) are available in Brazil. Thus, there are several anesthetic agents available for dental surgeons, what might lead them to opt for solutions that are more concentrated; however, more concentrated solutions may be less safe or have toxic effects in patients.

The risk with LAs-related systemic toxicity is the fact that, if delivered in excessive doses or injected directly into the bloodstream, they may cause major general effects. They are also capable of inducing a reversible blockade of action potentials on all excitable membranes, as a result of their mechanism of action, preventing the formation and conduction of impulses throughout the organic systems, especially the central nervous system (CNS). Tongue numbness, drowsiness, dizziness, seizures, or generalized CNS depression (final effect) can be included among the most relevant CNS effects associated with increased levels of LAs in plasma ${ }^{4-5}$.

Vasoconstrictor agents have been associated with LAs, considering that the amide-type LAs show vasodilating action, which increases their absorption rate and may increase their toxicity. Moreover, the addition of vasoconstrictors (VCs) extends the duration of anesthesia, reducing the need for using a large number of anesthetic cartridges. On the other hand, the excess or wrong prescription of these agents may be another source of systemic adverse effects in patients. In Brazil, adrenergic VCs (also called sympathomimetics) are available [including adrenaline (epinephrine; concentrations of $1: 50,000,1: 100,000$ or $1: 200,000)$, noradrenaline (norepinephrine, 1:50,000), phenylephrine $(1: 2,500)$ and levonordefrin $(1: 20,000)]$, and the non-adrenergic VC felypressin $(0.03 \mathrm{IU} / \mathrm{ml})$.

Adrenergic VCs have similar or identical chemical structure of the mediators of the sympathetic nervous system (epinephrine and norepinephrine) by binding to adrenergic receptors alpha $(\alpha)$ and beta $(\beta)$ in the body tissues. The activation of $\alpha 1$ receptor produces the contraction of smooth muscle in blood vessels (vasoconstriction); the binding to $\beta 1$ receptor, which is found in the heart and small intestine, induces cardiac stimulation and lipolysis; the stimulation of $\beta 2$, found in bronchial and uterine vascular beds, induces vasodilatation and bronchodilatation ${ }^{4-5,7}$. Excess of VCs may also cause systemic side effects associated with the stimulation of adrenergic receptors, including elevated systolic blood pressure and heart rate, and from simple palpitations to more serious cardiac arrhythmias. Cerebral hemorrhage can occur in dramatic increases in blood pressure or in patients with weakened vascular walls ${ }^{8}$. Besides patients with cardiovascular disease, those with uncontrolled diabetes may present some problems due to the stimulation of gluconeogenesis and glycogenolysis by these drugs ${ }^{9}$.

Epinephrine is the vasoconstrictor agent most commonly used in developed countries ${ }^{5,7}$. It has effects on adrenergic receptors $\alpha 1$ and vasoconstriction in some tissues, as well as vasodilatory effects on vascular tissues that contain predominantly $\beta 2$ adrenergic receptors. This antagonistic property of epinephrine limits the potential pressor effects of the drug as compared to other adrenergic VCs, which may cause major effects on systolic pressure, headache, palpitations or frequent fainting7,10-11. The use of $3 \%$ mepivacaine without vasoconstrictor or with the vasoconstrictor felypressin (a vasopressin's synthetic analogue in association with prilocaine) can be an alternative to the use of adrenergic $\mathrm{VCs}$, producing vasoconstriction in smooth muscle venules through the binding to receptors $\mathrm{V} 1$ and causing fewer cardiovascular side effects ${ }^{5-6}$.

The choice of the anesthetic solution should take into account, in addition to the mechanisms of action and side effects associated with both LAs and VCs, the length of the procedure, need for hemostasis, control of postoperative pain and patients' characteristics, especially those with special needs ${ }^{12-13}$, on whom should be particularly observed the maximum recommended rates for these substances, presented in form of milligrams of the drug per unit of body weight.

The variety of LAs and VCs available in Brazil might lead dentists to be uncertain of best choice of solution in 
each situation. Thus, considering this variety of agents and the possible involvement of systemic toxicity, the purpose of this study was to evaluate the anesthetic solutions (local anesthetic and vasoconstrictor) used by a group of dentists from private clinics, as well as the knowledge of these clinicians about the risks associated with these substances.

\section{METHODS}

This field research was approved by the Research Ethics Committee of the Ceuma University (process \#11006013.2.0000.5084). The survey was conducted in private dental clinics in São Luís, Maranhão, Brazil, between the months of April 2013 and January 2014.

One hundred and twenty-four (124) dentists agreed to participate. A questionnaire prepared by the authors and based on the Manual of Local Anesthesia ${ }^{16}$ was used for data collection, which was then completed by each participant at their work place after signing the consent form. In general, the questionnaire consisted of questions regarding the anesthetic solution of choice, number of solutions used in the clinic, selection criteria of solutions and awareness of side effects associated with both LAs and VCs. Signs and symptoms already observed by dentists or reported by patients during or after local anesthesia were also investigated.

After completion of the questionnaires, the data collected were organized in graphs and tables to be presented as descriptive statistics, using the Word and Excel programs, Microsoft Office 2013 package.

\section{RESULTS}

Most dentists (38.7\%) who participated in this study obtained a degree of Doctor of Dental Surgery (DDS) in the last five years, whereas $18.5 \%$ of them had obtained it within the last 15 years (Table 1). Upon completion of the questionnaires, forty-six professionals $(32.1 \%)$ reported have been working as general practitioners.

Table 1. Time since the obtainment of a DDS degree by the participants of the study (conducted with dentists from private clinics in São Luís (Brazil) from April 2013 to January 2014).

\begin{tabular}{lcc}
\hline Years & $\mathrm{n}$ & $\%$ \\
\hline $1-5$ & 48 & 38,7 \\
$6-10$ & 30 & 24,1 \\
$11-15$ & 23 & 18,5 \\
$16-20$ & 10 & 8,0 \\
$>20$ & 13 & 10,4 \\
Total & 124 & 100 \\
\hline
\end{tabular}

Almost all the clinicians selected (83.7\%) reported have been using more than one anesthetic solution in their private clinics, while $60.4 \%$ (75 respondents) of the total sample has been using two anesthetic solutions, as shown in Figure 1.

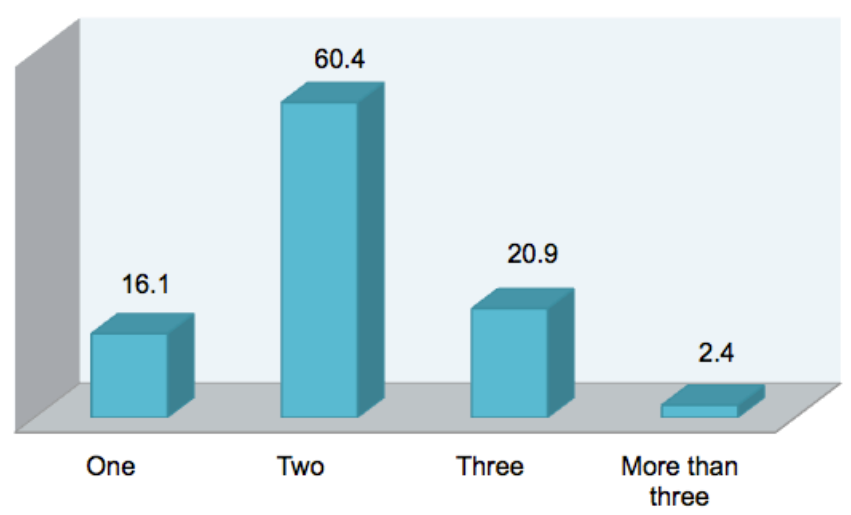

Figure 1. Amount of local anesthetic solutions used in private clinics by the dentists interviewed.

When asked about the anesthetic of choice, the following solutions were chosen: $2 \%$ lidocaine with epinephrine $1: 100,000$ (42.4\% of the dentists), $2 \%$ mepivacaine with epinephrine $1: 100,000$ (40\% of the dentists) and 4\% articaine with epinephrine 1:100,000 or 1:200,000 (8\%) (Figure 2). Other mentioned solutions, which would be the second or third choices of these professionals, are shown in Figure 2; despite a combination of $2 \%$ lidocaine with phenylephrine $1: 2,500$ is not commercially available in Brazil.

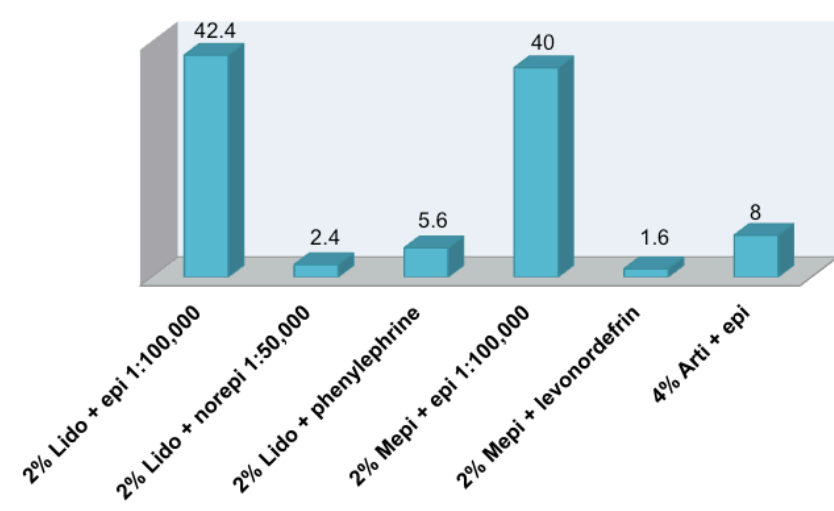

Caption: "2\% Lido + epi 1:1:100.000" = 2\% lidocaine with epinephrine 1:100,000 $" 2 \%$ Lido + norepi 1:50.000" $=2 \%$ Lidocaine with norepinephrine 1:50,000; " $2 \%$ Lido + phenylephrine 1:2500" = $2 \%$ Lidocaine with phenylephrine 1:2,500; "2\% Mepi + epi 1:100.000" = 2\% Mepivacaine with epinephrine 1:100,000; "2\% Mepi + levonordefrin $1: 20.000 "=2 \%$ Mepivacaine with levonordefrin 1:20,000; "4\% Arti + epi" $=4 \%$ Articaine with epinephrine $1: 100,000$ or $1: 200,000$ ).

Figure 2. First choice of local anesthetic solutions reported by dentists from private clinics in São Luís, Brazil (April 2013 to January 2014). 
When questioned about the selection criteria of anesthetic solutions, the clinicians could have chosen more than one option in the questionnaire; the duration of the clinical procedure and the characteristics of the patient were the most frequent choices. Only 15 (10\%) of respondents reported have been considering the toxicity of local anesthetics or vasoconstrictors while choosing the anesthetic. Table 2 shows data regarding the selection criteria of anesthetic solutions.

Table 2. Selection criteria for the use of local anesthetic solutions according to the participants of this study, conducted with dentists from private clinics in São Luís (Brazil), 2013-2014.

\begin{tabular}{lcc}
\hline Selection criteria & $\mathrm{n}$ & $\%$ \\
\hline Duration of the procedure & 85 & 38,6 \\
Hemostasis need & 15 & 6,8 \\
Toxicity of the local anesthetic and/or & 22 & 10 \\
vasoconstrictor & & \\
Patient characteristics & 88 & 40 \\
Cost & 6 & 2,7 \\
Others & 4 & 1,8 \\
\hline
\end{tabular}

The signs and symptoms reported by professionals, which were seen at least once after performing local anesthesia in patients, are shown in Table 3. The sign "slurred speech" and the symptom "tachycardia" were the most common.

Table 3. Signs and symptoms already observed by dentists from private clinics in São Luís (Brazil) after local anesthesia in patients.

\begin{tabular}{lcc}
\hline Signs and symptoms & $\mathrm{n}$ & $\%$ \\
\hline Tachycardia & 47 & 20,8 \\
Slurred speech & 23 & 10,2 \\
Tongue numbness & 12 & 5,3 \\
Somnolence & 15 & 6,6 \\
Convulsion & 3 & 1,3 \\
Cardiac arrest & 0 & 0 \\
Swoon & 9 & 4 \\
Pallor & 42 & 18,6 \\
Dizziness & 37 & 16,4 \\
None & 34 & 15,1 \\
Other / headache / vomiting & 3 & 1,3 \\
\hline
\end{tabular}

Finally, these professionals were investigated in terms of the knowledge of possible patients' signs/symptoms and LAs or VCs' toxicity. The questionnaire had the same options of signs/symptoms to be chosen for the toxicity related to either LAs or VCs, which were the following: change of heart rate, increase in blood pressure, drowsiness, tongue numbness, slurred speech or none of these.

Sixty-six respondents (37.5\%) said that "changes in heartbeat" were signs of local anesthetic toxicity, and thirty respondents (17\%) did not involve any of the signs/ symptoms in the questionnaire with local anesthetic toxicity. Regarding the vasoconstrictor, $90(45.4 \%)$ respondents associated an "increase in blood pressure" with the toxicity of these substances, followed by "changes in heartbeat" (33.8\% of respondents). Fourteen percent $(14 \%)$ of the dentists said that none of the signs/symptoms listed was related to the toxicity of vasoconstrictors. The results with the percentage of all signs/symptoms mentioned are described in Tables 4 and 5.

Table 4. Signs and symptoms associated with the toxicity of local anesthetics according to dentists from private clinics in São Luís.

\begin{tabular}{lcc}
\hline Signs and symptoms & $\mathrm{n}$ & $\%$ \\
\hline Changes in heartbeat & 66 & 37,5 \\
Increase in blood pressure & 31 & 17,6 \\
Somnolence & 18 & 10,2 \\
Tongue numbness & 9 & 5,1 \\
Slurred speech & 21 & 11,9 \\
None of these & 30 & 17 \\
Did not answered & 1 & 0,5 \\
\hline
\end{tabular}

Table 5. Signs and symptoms associated with the toxicity of vasoconstrictors according to dentists from private clinics in São Luís.

\begin{tabular}{lcc}
\hline Signs and symptoms & $\mathrm{n}$ & $\%$ \\
\hline Changes in heartbeat & 67 & 33,8 \\
Increase in blood pressure & 90 & 45,4 \\
Somnolence & 7 & 3,5 \\
Tongue numbness & 10 & 5 \\
Slurred speech & 10 & 5 \\
None of these & 14 & 7 \\
\hline
\end{tabular}

\section{DISCUSSION}

In the present study, it was observed that the majority of dentists evaluated, have been using local anesthetic and vasoconstrictors solutions at low concentrations and toxicity. However, it was found that there was a lack of knowledge in terms of the aspects of systemic toxicity of these substances, especially local 
anesthetics, when used in overdoses. Such relevant data highlights the need for greater pharmacological knowledge about these chemicals largely used by dentists.

The study participants showed a preference for $2 \%$ mepivacaine/lidocaine, both associated with epinephrine 1:100,000. Lidocaine and mepivacaine are similar anesthetics in terms of the latency time and maximum recommended doses $(4.4 \mathrm{mg} / \mathrm{kg})$, both being indicated for use in clinical procedures of medium length, which corresponds to most dental procedures ${ }^{5}$. The increased use of mepivacaine can be explained by the fact that most of the clinicians reported that the duration of anesthesia was the main selection criteria of the anesthetic, considering that mepivacaine provides a slightly longer anesthetic effect compared to lidocaine. However, it is important to consider that, in some cases, especially in pregnant and lactating women, it is preferable to opt for lidocaine, inasmuch as the hepatic metabolism of mepivacaine was found to be about 2-3 times slower than lidocaine in the newborn ${ }^{12}$.

In terms of the choice of vasoconstrictors, a widespread use of epinephrine 1:100,000 was found, which is actually the most widely used vasoconstrictor in developed countries ${ }^{5}$. Epinephrine is usually the most suitable vasoconstrictor in dentistry as a result of the stimulation of both $\alpha 1$ and $\beta 2$ receptors), providing reduced cardiovascular effects compared to other adrenergic vasoconstrictors with lower $\beta_{2}$ stimulation ${ }^{4-5,7}$.

On the other hand, an interesting fact observed in the study was that most of the dentists reported having in their clinics two or more anesthetic solutions; however, the second option reported by each dentist also contained epinephrine in its composition. One can speculate that, although most individuals have responded that vasoconstrictors could be involved in heart rate changes and increased blood pressure in case they were used inappropriately, the choice of epinephrine as a second option suggests that the dentists do not understand the mechanism of action as well as the potential toxicity of epinephrine, especially in patients with special needs. In short, the professionals do not seem to pay attention to the fact that there is no advantage in having two solutions containing epinephrine whether both of them have very similar duration of action. This same line of reasoning questions the choice of the option "characteristics of the patient" by the respondents when they were asked about the criteria for selecting anesthetic solutions. Felypressin, the only non-adrenergic vasoconstrictor mentioned, which could be an alternative to the use of adrenergic vasoconstrictors, was not chosen as a second option by any of the respondents.

Although the use of epinephrine in patients with some special needs (i.e. controlled diabetes, hypertension and cardiovascular diseases) is still controversial, it is thought to be appropriate to these patients provided that a proper anesthetic technique is adopt, with minimal injection of the solution (concentrations lower than or equal to 1:100,000, and a maximum of two anesthetic cartridges) and previous aspiration ${ }^{12-13}$. On the other hand, the use of vasoconstrictors should be avoided in patients with high risk of cardiovascular disease and uncontrolled diabetes. In such cases or when emergency procedures are required, it is suggested to opt for $3 \%$ prilocaine with felypressin $(0.03$ $\mathrm{IU} / \mathrm{ml}$ ) or $3 \%$ mepivacaine without vasoconstritor ${ }^{8}$.

Few respondents reported have been considering the toxicity of local anesthetic or vasoconstrictor for the choice of anesthetic solution; however, anesthetic solutions with higher toxic effects were not mentioned (i.e. $3 \%$ lidocaine with norepinephrine $1: 50,000$ or $2 \%$ mepivacaine with levonordefrin 1:20,000). It is still possible that these results are related to the fact the sample consisted mostly of recent graduate dentists (up to 5 years since the obtainment of a DDS degree), who might have been exposed to updated information about the anesthetic solutions most frequently indicated; not opting, therefore, for anesthetics/vasoconstrictors with higher toxicity, even with limited information about these agents.

It is noteworthy that some dentists were not sure whether the signs and symptoms were caused as a result of local anesthetics or vasoconstrictors toxicity. In addition, a considerable number of dentists did not identify in the questionnaire any sign or symptom related to anesthetics' overdose. Hence, it is suggested that more continuing education programs or professional development courses are conducted towards providing a better understanding of the systemic effects of both anesthetics and vasoconstrictors to the dentists, especially because the majority of them reported have observed signs or symptoms after anesthetic procedure in patients.

In addition to the parameters evaluated in this study, clinicians need to be aware of the potential of other factors such as phobias, chair position, anxiety, inadvertent administration, intolerance and idiosyncrasies, liver or kidney diseases, maximum recommended doses, own 
security protocols, and concomitant drug interactions. Furthermore, there is a risk of allergic reactions following the injections of local anesthetics, frequently due to preservatives (i.e. methylparaben) or antioxidants (i.e. sulfites) contained in the solutions s,10,14. $^{\text {. }}$

Yet, anamnesis is extremely important as a complete medical and dental history, being the most simple and efficient method for detection of risk factors which can trigger adverse events. Compliance with the guidelines of the local anesthetic doses is the first and most important strategy towards preventing adverse events; dosage calculations are recommended in order to avoid unexpected systemic reactions $\mathrm{s}^{4-5,14}$.

In present study, it was still observed that there is a tendency for mixing the signs and symptoms of anesthetic toxicity with those related to the vasoconstrictor, which may lead to mistakes in the selection or application of the solution, especially when dealing with patients with special needs.

\section{REFERENCES}

1. Clark TM, Yagiela JA. Advanced techniques and armamentarium for dental local anesthesia. Dent Clin North Am. 2010;54(4):75768. doi: 10.1016/j.cden.2010.06.017

2. Finder RL, Moore PA. Adverse drug reactions to local anesthesia. Dent Clin North Am. 2002; 46(4):747-57

3. Moore PA, Hersh EV. Local anesthetics: pharmacology and toxicity. Dent Clin North Am. 2010;54(4):587-99. doi: 10.1016/j. cden.2010.06.015

4. Becker DE, Reed KL. Essentials of local anesthetic pharmacology. Anesth Prog. 2006;53(3):98-108.

5. Becker DE, Reed KL. Local anesthetics: review of pharmacological considerations. Anesth Prog. 2012;59(2):90-101.

6. Chiu CY, Lin TY, Hsia SH, Lai SH, Wong KS. Systemic anaphylaxis following local lidocaine administration during a dental procedure. Pediatr Emerg Care. 2004;20(3):178-80.

7. Hersh EV, Giannakopoulos H. Beta-adrenergic blocking agents and dental vasoconstrictors. Dent Clin North Am. 2010;(54):68796.

8. Conrado VC, Andrade J, Angelis GA, Andrade AC, Timerman L, Andrade MM, et al. Efeitos cardiovasculares da anestesia local com vasoconstritor durante exodontia em coronariopatas. Arq Bras Cardiol. 2007;88(5):446-52.

9. Clutter WE, Bier DM, Shah SD, Cryer PE. Epinephrine plasma metabolic clearance rates and physiologic thresholds for metabolic and hemodynamic actions in man. J Clin Invest. 1980;66(1):94-101.

\section{CONCLUSION}

Although the participants were found to be likely to choose anesthetic solutions of lower toxicity, they were also found to be mostly unaware of possible side effects of local anesthetics/vasoconstrictors overdoses. Thus, we suggest that strategies towards increasing the knowledge of dentists working in private clinics about the systemic toxicity of local anesthetics should be encouraged.

\section{Acknowledgements}

The authors would like to thank the financial support of the Foundation for the Support of Scientific and Technological Development in the State of Maranhão (FAPEMA; BM process \#1418/2012), and all dentists who participated in the study.

10. van der Bijl P, Victor AM. Adverse reactions associated with norepinephrine in dental local anesthesia. Anesth Prog. 1992;39(3):87-9.

11. Meechan J. How to avoid local anaesthetic toxicity. Br Dent J. 1998;184(7):334-55.

12. Brown WU, Bell GC, Lurie AO, Weiss B, Scanlon JW, Alper $\mathrm{MH}$. New born blood levels of lidocaine and mepivacaine in the first post natal day following maternal epidural anesthesia. Anesthesiology. 1975;42(6):698-70.

13. Volpato MC, Ranali J, Ramacciato JC, De Oliveira PC, Ambrosano GM, Groppo FC. Anesthetic efficacy of bupivacaine solutions in inferior alveolar nerve block. Anesth Prog. 2005;52(4):132-5.

14. Speca SJ, Boynes SG, Cuddy MA. Allergic reactions to local anesthetic formulations. Dent Clin North Am. 2010;54:65564.

15. Oliveira AEM, Simone JL, Ribeiro RAR. Pacientes hipertensos e a anestesia na Odontologia: devemos utilizar anestésicos locais associados ou não com vasoconstritores? HU Revista. 2010;36(1):69-75.

16. Malamed SF. Manual de anestesia local. $6^{\text {a }}$ ed. Rio de Janeiro: Elsevier; 2013. 